\title{
Pemetaan Ekonomi Kreatif Subsektor Kuliner di Kota Pontianak
}

\author{
Metasari Kartika* \\ Universitas Tanjungpura \\ Hendarmin \\ Universitas Tanjungpura
}

\begin{abstract}
This study aims to map the creative economy culinary subsector of Pontianak City in 2017 based on Creative Economy Indonesian Standard Industrial Classification (ISIC) and structure-conductperformance (SCP) approach. This study also maps the characteristic of creative economy actor culinary subsector based on age and education, as well as observes the creativity of culinary subsector in Pontianak City. This study used qualitative descriptive method with study object in Pontianak City. The sampling method used was stratified random sample with 287 total samples. The result was the creative economy scopes in Pontianak City mostly are restaurants, stalls, and café. The economy creative actor for culinary subsector in Pontianak is 40 years old in average and 51.2\% had high school as their educational background. The creativity of culinary subsector in Pontianak City were involving the trained chef, routinely creates new menu, consists the local cuisine, gives culinary experience for the consumers, and used technology. Based on the SCP approach (1) culinary business model in Pontianak City are independent and the average belonging to small and medium enterprises, (2) $79.8 \%$ of the creative economy actors stated they determine the price by themselves; 120 respondents determined their own prices after finding out their rival's prices, (3) marketing strategy still use word of mouths marketing technique.
\end{abstract}

Keywords: economy, creative, culinary, mapping

\section{PENDAHULUAN}

Evolusi perekonomian memunculkan istilah ekonomi kreatif yang memberikan warna tersendiri. Kata "kreatif" bermakna bahwasanya beberapa kegiatan produksi barang/jasa jika terdapat sentuhan kreatifitas akan menambah nilai output barang/jasa tersebut. Kementerian Pariwisata dan Ekonomi Kreatif RI (2010, p.4) menekankan bahwa dimasa depan kedudukan ekonomi kreatif akan menjadi penting karena bersumber pada kreativitas yang merupakan sumber daya terbarukan. Hal inilah yang menjadikan

\footnotetext{
* Korespondensi: Metasari Kartika, Jurusan Ilmu Ekonomi dan Studi Pembangunan, Fakultas Ekonomi dan Bisnis, Universitas Tanjungpura, Jalan Prof. Dr. H. Hadari Nawawi Pontianak 78124. Email: metasarikartika@gmail.com
} 
ekonomi kreatif dapat berperan sebagai komponen penggerak pertumbuhan ekonomi, penyerapan tenaga kerja, perdagangan dan inovasi (Carr, 2009).

Kuliner sebagai salah satu dari lima belas subsektor di dalam ekonomi kreatif, merupakan kegiatan persiapan, pengolahan, penyajian produk makanan dan minuman yang menjadikan unsur kreativitas, estetika, tradisi, dan kearifan lokal sebagai elemen terpenting dalam meningkatkan cita rasa dan nilai produk untuk menarik daya beli dan memberikan pengalaman bagi konsumen (Lazuardi \& Triady, 2015). Kuliner menjadi bagian dari ekonomi kreatif merupakan subsektor yang potensial bagi sektor lainnya. Kuliner juga mempunyai peran strategis dalam memperkuat identitas bangsa Indonesia (Menteri Pariwisata RI, 2016). Unsur kreatifitas pada subsektor kuliter terdapat dalam hal penyajian, estetika, budaya lokal yang menunjang cita rasa sehingga menarik minat masyarakat untuk membeli. Kreatifitas pada subsektor kuliner menstimulasi tumbuhnya perusahaan yang bergerak pada subsektor ini. Kontribusi jumlah perusahaan subsektor kuliner terhadap jumlah perusahaan ekonomi kreatif dari tahun 2010-2013 rata-rata 56,09\% (Lazuardi \& Triady, 2015).

Berkembangnya aktivitas ekonomi kreatif subsektor kuliner memberikan dampak positif bagi perekonomian. Kreatifitas mengakibatkan subsektor ini memberikan nilai tambah bagi ekonomi kreatif dan PDB. Kontribusi subsektor kuliner masih berpotensi semakin besar dikarenakan perubahan gaya hidup masyarakat, kekayaan budaya, sumber daya alam yang dimiliki suatu daerah. Untuk itu diperlukan strategi pengembangan untuk memaksimalkan kontribusi ekonomi kreatif subsektor kuliner terhadap perekonomian nasional dan khususnya bagi perekonomian daerah. Strategi pengembangan ditentukan berdasarkan pemetaan dan identifikasi awal ekonomi kreatif subsektor kuliner berdasarkan structure-conduct-performance

Kota Pontianak adalah kota khatulistiwa yang telah memiliki 17.000 pelaku usaha UMKM dan menjadi 10 besar kota ekonomi kreatif (Triwibowo, 2016). Sektor andalan Kota Pontianak yakni sektor : (1) perdagangan besar dan eceran, reparasi mobil dan sepeda motor ; (2) industri pengolahan, dan (3) konstruksi. Pada industri pengolahan, subsektor industri makanan dan minuman memberikan kontribusi sebesar $57 \%$ pada tahun 2015. Selain itu, Kota Pontianak merupakan kawasan perkotaan dan ibukota propinsi yang memiliki aneka ragam kuliner daerah. Potensi ini perlu dikembangkan agar memberikan kontribusi bagi perekonomian daerah sehingga peran pelaku ekonomi kreatif sangat dibutuhkan di Kota Pontianak. Saat ini masih sedikit kajian dan pemetaan mengenai ekonomi kreatif subsektor kuliner di Kota Pontianak. Oleh karenanya tujuan dari penelitian ini adalah untuk mengetahui karakteristik dan kreatifitas ekonomi kreatif subsektor kuliner di Kota Pontianak serta mengetahui structure-conduct-performance ekonomi kreatif subsektor kuliner di Kota Pontianak 


\section{KAJIAN LITERATUR}

\section{Konsep Ekonomi Kreatif}

Ekonomi kreatif pada hakikatnya adalah kegiatan ekonomi yang mengutamakan pada kreativitas berpikir untuk menciptakan sesuatu yang baru dan berbeda yang memiliki nilai dan bersifat komersial (Suryana, 2013). Hasil kreatifitas berfikir melahirkan inovasi yang menjadi bagian dalam menentukan kesejahteraan dan kinerja perekonomian dalam jangka panjang sebagaimana inovasi tersebut menjadi pengaruh dalam kinerja sebuah perusahaan (Bakhshi, MacVittie, \& Simmie, 2008).

Ekonomi kreatif erat kaitannya dengan industri kreatif, namun ekonomi kreatif memiliki cakupan yang lebih luas dari industri kreatif. Ekonomi kreatif merupakan ekosistem yang memiliki hubungan saling ketergantungan antara rantai nilai kreatif (creative value chain); lingkungan pengembangan (nurturance environment); pasar (market) dan pengarsipan (archiving) (Kementerian Pariwisata dan Ekonomi Kreatif RI, 2014). Berdasarkan definisi tersebut maka ekonomi kreatif tidak hanya memberikan nilai tambah secara ekonomi tetapi juga memberikan penciptaan nilai tambah secara sosial, budaya dan lingkungan. Industri kreatif merupakan bagian dari ekonomi kreatif. Department for Culture, Media and Sport's (DCMS) Inggris mendefinisikan industri kreatif sebagai kegiatan yang berasal dari kreatifitas, keahlian, bakat dan memiliki potensi untuk memberikan nilai tambah melalui eksploitasi kekayaan intelektual yang dimiliki (Miles \& Green, 2008). Sedangkan pemerintah Indonesia melalui Kementerian Pariwisata dan Ekonomi Kreatif (2014) mendefinisikan industri kreatif sebagai industri yang menghasilkan output dari pemanfaatan kreativitas, keahlian, dan bakat individu untuk menciptakan nilai tambah, lapangan kerja, dan peningkatan kualitas hidup.

Dalam pengembangan ekonomi kreatif dibutuhkan sinergisitas peran pemerintah, intelektual dan bisnis, yang kemudian disebut sistem triple helix (Moelyono, 2010). Sistem triple helix kini telah disempurnakan dengan sistem quad helix yang melibatkan peran masyarakat dalam pengembangan ekonomi kreatif. Masyarakat juga melakukan inovasi seiring adanya perkembangan sektor pelayanan publik, internet dan era globalisasi (Kimatu, 2016). Sistem quad helix telah digunakan oleh Pemerintah Indonesia dalam menyusun Rencana Induk Pengembangan Ekonomi Kreatif 2015-2025 dan Rencana Aksi Jangka Menengah Ekonomi Kreatif 2015-2019 (Kementerian Pariwisata dan Ekonomi Kreatif RI, 2014). Pembangunan ekonomi kreatif dalam 5 tahun tidak terbatas hanya pada pengembangan 15 subsektor ekonomi kreatif yaitu (1) arsitektur; (2) desain; (3) film, video, dan fotografi; (4) kuliner; (5) kerajinan; (6) mode; (7) musik; (8) penerbitan; (9) permainan interaktif; (10) periklanan; (11) penelitian dan pengembangan; (12) seni rupa; (13) seni pertunjukan; (14) teknologi informasi; dan (15) televisi dan radio, tetapi juga berupaya pada pengarusutamaan ekonomi kreatif dalam setiap sektor ekonomi. Maksud dari pengarusutamaan adalah bagaimana menjadikan ekonomi kreatif sebagai sektor penggerak di setiap sektor ekonomi melalui pemanfaatan iptek, design thinking, berorientasi budaya lokal, dan pemanfaatan media secara optimal 
untuk meningkatkan literasi dan konsumsi pasar di dalam negeri (Kementerian Pariwisata dan Ekonomi Kreatif RI, 2014).

Ekonomi kreatif subsektor kuliner merupakan kegiatan persiapan, pengolahan, penyajian produk makanan dan minuman yang menjadikan unsur kreativitas, estetika, tradisi, dan/atau kearifan lokal sebagai elemen terpenting dalam meningkatkan cita rasa dan nilai produk tersebut, untuk menarik daya beli dan memberikan pengalaman bagi konsumen (Lazuardi \& Triady, 2015). Berdasarkan Klasifikasi Baku Lapangan Usaha Indonesia (KBLI) 2009, belum ada kategori lapangan usaha yang ditujukan khusus untuk kode usaha industri kreatif kuliner. Hal ini dikarenakan kuliner merupakan subsektor baru yang dimasukkan pada industri kreatif, sekitar pada tahun 2011. Sesuai KBLI Ekonomi Kreatif, ruang lingkup subsektor kuliner adalah:

1. 56101 Restoran

2. 56102 Warung Makan

3. 56103 Kedai Makanan

4. 56104 Penyediaan Makanan Keliling Atau Tempat Tidak Tetap

5. 56210 Jasa Boga Untuk Suatu Event Tertentu (Event Catering)

6. 56290 Penyediaan Makanan Lainnya

7. 56301 Bar

8. 56302 Kelab Malam Atau Diskotik Yang Utamanya Menyediakan Minuman

9. 56303 Rumah Minum Atau Kafe

10. 56304 Kedai Minuman

11. 56305 Rumah Atau Kedai Obat Tradisional

12. 56306 Penyediaan Minuman Keliling Atau Tempat Tidak Tetap

\section{Pendekatan Structure - Conduct - Performance}

Pasar kuliner tergolong pasar monopilistik dengan banyak pembeli dan penjual sehingga membutuhkan diferensiasi produk. Oleh karena itu pelaku usaha dituntut kreatifitasnya agar dapat bertahan di pasar ini. Pendekatan SCP digunakan untuk mengamati ekonomi kreatif subsektor kuliner di Kota Pontianak sehingga dapat menjadi kerangka analisis dasar dalam mengembangkan potensi subsektor ini.

Dalam suatu industri ada tiga hal yang selalu menjadi perhatian, dikenal dengan paradigma Structure-Conduct-Performance (SCP) yaitu struktur pasar industri tersebut, perilaku industri dalam pasar, dan kinerjanya. Ketiga hal ini sangat berkaitan erat dan saling mempengaruhi. Struktur pasar mempengaruhi perilaku, selanjutnya perilaku pasar menentukan kinerja pasar (Mahesa, 2010). Teori Structure- Conduct - Performance 
(SCP) menjelaskan bahwa kinerja suatu industri pada dasarnya sangat dipengaruhi oleh struktur pasar. Struktur pasar (structure) dianggap akan mempengaruhi perilaku dan strategi perusahaan dalam suatu industri dan perilaku (conduct) akan mempengaruhi kinerja (performance). Paradigma SCP berpendapat bahwa konsentrasi pasar yang tinggi membuat perusahaan lebih mudah untuk menguasai pasar dan menghasilkan keuntungan atau marjin yang tinggi (Khavidhurrohmaningrum, 2013).

Struktur pasar merupakan suatu pola dimana elemen-elemen dalam industri saling berinteraksi, baik antara penjual, antara pembeli, antara penjual dan pembeli, maupun antara penjual yang sudah ada dengan calon pesaing yang akan masuk ke pasar (Arsyad, L., \& Kusuma, 2014). Struktur pasar mengindikasikan kondisi persaingan yang ada di pasar. Struktur terkait dengan seberapa tinggi derajat konsentrasi penjual (jumlah penjual dan distribusi penjualan), derajat konsentrasi pembeli (jumlah pembeli dan distribusi pembelian), derajat differensiasi produk (seberapa tingkat variasi produk) dan hambatan untuk terjadinya kompetisi (seberapa tinggi tingkat kesulitan yang ditemui oleh pesaing untuk masuk ke dalam industri). Struktur pasar cenderung mempengaruhi perilaku perusahaan dalam menjalankan bisnisnya. Perilaku merupakan pola perilaku yang diikuti oleh perusahaan-perusahaan yang ada di pasar untuk menyesuaikan diri dengan kondisi pasar dalam rangka mencapai tujuan perusahaan masing-masing. Elemen perilaku mencakup penentuan harga, jenis, kuantitas produk yang diproduksi, penentuan standar proses dan kualitas produk, strategi periklanan, penelitian dan pengembangan serta berbagai bentuk praktik persaingan maupun kerjasama (kolusi) yang ada dalam industri. Dalam pendekatan SCP, perilaku diasumsikan mempengaruhi kinerja perusahaan dalam industri. Kinerja tercermin dari tingkat profitabilitas, efisiensi dan pertumbuhan perusahaan dalam industri, maupun sejumlah variabel lain.

\section{Penelitian Terdahulu}

Penelitian tentang pengembangan ekonomi kreatif di pedesaan (Fleming, 2009). Objek penelitian melibatkan seniman, perencana kebijakan dan penduduk di Chatham County, North Carolina, Amerika Serikat. Fleming menyebutkan bahwa proyek pengembangan ekonomi kreatif sangat tepat dilakukan untuk pembangunan daerah pedesaan secara berkelanjutan, walaupun manfaat dan tantangan yang dihadapi dalam mengembangkan ekonomi kreatif ini belum dipahami. Menggunakan metodologi penelitian deskriptif kualitatif, peneliti berpendapat pengembangan ekonomi kreatif juga dipandang sebagai strategi ekonomi yang lebih efektif dibandingkan strategi lainnya. Peneliti juga menyimpulkan bahwa dalam kenyataannya, sisi kreatifitas dan ekonomi memiliki arah yang sejalan.

Studi Industri Kreatif Indonesia (Departemen Perdagangan RI, 2009) melakukan pemetaan industri kreatif dengan tahapan-tahapan berupa studi literatur, focus group discussion, pembuatan kisi model, pengumpulan dan pengolahan data serta analisis 
mengenai profil kontribusi ekonomi sektor industri kreatif terhadap total indikator ekonomi Indonesia dan profil kontribusi ekonomi kelompok industri kreatif. Kesimpulan studi ini adalah berdasarkan pemetaan lapangan usaha sektor industri kreatif dapat diidentifikasikan 14 kelompok industri kreatif di Indonesia dan menurut Klasifikasi Baku Lapangan Usaha Indonesia (KBLI) versi tahun 2005, masih banyak lapangan usaha industri kreatif yang belum diidentifikasikan dalam KBLI tersebut. Penelitian ini juga menghitung besarnya kontribusi ekonomi kreatif bagi perekonomian di Indonesia pada tahun 2006 dengan kontribusi nilai tambah bruto (NTB) sebesar 104,787 Triliun Rupiah, tenaga kerja yang terserap berjumlah 4,9 juta orang, jumlah perusahaan yang bergerak di industri kreatif berjumlah 2,189 juta perusahaan dan pertumbuhan ekspor yang dihasilkan sebesar $8,21 \%$.

Penelitian mengenai tiga pendekatan pemetaan tenaga kerja di industri kreatif (Higgs \& Cunningham, 2008). Pemetaan pertama, lingkup yang terbatas dimana jumlah tenaga kerja kreatif hanya dihitung dari jumlah tenaga kerja di industri kreatif. Pemetaan kedua, jumlah tenaga kerja kreatif adalah penjumlahan antara tenaga kerja yang bekerja di industri kreatif dan bekerja di pekerjaan yang menuntut kreatifitas tetapi di industri lainnya. Pemetaan ketiga, tenaga kerja kreatif merupakan penjumlahan tenaga kerja yang bekerja pada: pekerjaan kreatif di industri kreatif, pekerjaan pendukung di industri kreatif dan pekerjaan kreatif di industri lainnya. Pemetaan ketiga ini kemudian disebut dengan metodologi Creative Trident. Metodologi pemetaan ini dinilai lebih memiliki keunggulan dibandingkan dua pemetaan sebelumnya dan memiliki implikasi yang penting bagi strategi industri dan pemerintah sebagai pembuat kebijakan. Melalui metodologi Creative Trident, memberikan cakupan informasi yang lebih luas mengenai ekonomi kreatif dengan fokus pada sumber daya manusia.

Penelitian selanjutnya melakukan analisis deskriptif dalam menjelaskan perilaku industri minuman di Indonesia dan menggunakan analisis kuantitatif untuk menganalisis struktur pasar industri minuman di Indonesia (Mahesa, 2010). Adapun metode kuantitatif yang digunakan adalah rasio konsentrasi dan Indeks Herfindhal Hirschman (IHH). Kesimpulannya yaitu struktur pasar yang dimiliki oleh industri minuman Go publik di Indonesia adalah struktur persaingan oligopoli, Penetapan harga oleh suatu perusahaan dalam industri minuman akan dipengaruhi oleh penetapan harga oleh pesaingnya dan perilaku konsumen juga masih diperhitungkan dalam menentukan harga. Struktur pasar oligopoli yang ketat ini mengindikasikan kecendrungan pasar industri minuman GoPublik di Indonesia semakin tidak kompetitif atau terkonsentrasi, sehingga Mahesa (2010) menyarankan diperlukannya pengawasan oleh pemerintah untuk mengawasi kegiatan usaha yang terindikasi memiliki posisi terlalu dominan dan menyulitkan pendatang baru pada industri minuman Go Publik di Indonesia. Di sisi lainnya, industri minuman harus dapat mempertahankan penjualan dan pangsa pasar yang telah dicapai dan diharapkan dapat menguasai pangsa pasar internasional kedepanya dengan strategi strategi yang kritis. 
Khavidhurrohmaningrum menjelaskan bagaimana struktur dan perilaku industri pengolahan di Kota Semarang (Khavidhurrohmaningrum, 2013). Metode yang digunakan dalam penelitiannya adalah analisis rasio konsentrasi (CR) yaitu CR4, CR8 dan Indeks Herfindahl. Penelitian ini juga menggunakan Minimum Efficiency Scale untuk melihat bagaimana hambatan masuk pasar pada industri pengolahan. Berdasarkan hasil analisis CR4 dan CR8 ditemukan bahwa struktur industri pengolahan di Kota Semarang berbentuk oligopoli penuh dan berdasarkan analisis indeks Herfindahl menunjukkan bahwa struktur industri di Kota Semarang memiliki struktur perusahaan dominan. Adapun mengenai hambatan masuk industri pengolahan di Kota Semarang cukup tinggi dengan nilai Minimum Efficiency Scale (MES) yaitu sebesar 30,18 persen. Selain itu disimpulkan bahwasanya pada kondisi struktur pasar oligopoli, perilaku pasar yang dilakukan adalah dengan strategi penurunan harga. Untuk strategi promosi produk dapat dilakukan pada industri furniture dan industri pengolahan lainnya.

\section{METODA PENELITIAN}

Metodologi yang digunakan adalah deskriptif kualitatif. Data dikumpulkan pada tahun 2017 dengan metode menyebarkan kuisioner. Objek penelitian adalah enam kecamatan di Kota Pontianak yakni Kecamatan Pontianak Kota, Kecamatan Pontianak Selatan, Kecamatan Pontianak Tenggara, Kecamatan Pontianak Barat, Kecamatan Pontianak Timur, dan Kecamatan Pontianak Utara.

\section{Tabel 1. Populasi dan Sampel Pelaku Usaha Ekonomi Kreatif di Kota Pontianak}

\begin{tabular}{llrrr}
\hline No & Kecamatan & Populasi & \multicolumn{1}{c}{ Nilai f } & Sampel \\
\hline 1 & Pontianak Timur & 213 & $213 / 1.022=0,21$ & $0,21 \times 287=60$ \\
2 & Pontianak Utara & 209 & $209 / 1.022=0,20$ & $0,20 \times 287=57$ \\
3 & Pontianak Barat & 205 & $205 / 1.022=0,20$ & $0,20 \times 287=57$ \\
4 & Pontianak Kota & 213 & $213 / 1.022=0,21$ & $0,21 \times 287=60$ \\
5 & Pontianak Tenggara & 142 & $142 / 1.022=0,14$ & $0,14 \times 287=40$ \\
6 & Pontianak Selatan & 40 & $40 / 1.022=0,04$ & $0,04 \times 287=11$ \\
\hline & TOTAL & $\mathbf{1 . 0 2 2}$ & $\mathbf{1}$ & $\mathbf{2 8 7}$ \\
\hline
\end{tabular}

Jumlah usaha kuliner yang terdata di Dinas Koperasi, Usaha Mikro Perdagangan Kota Pontianak pada tahun 2016 dan 2017 sebanyak 1.022. Teknik pengambilan sampel menggunakan stratified random sampling dan perhitungan total sampel didapatkan dari rumus slovin : $\mathbf{n}=\mathbf{N} /\left(\mathbf{1}+\mathbf{N e}^{\mathbf{2}}\right)$. Dimana $\mathrm{n}$ adalah total sampel, $\mathrm{N}$ adalah jumlah populasi dan e pada tingkat $5 \%$, sehingga didapatkan total sampel sebanyak 287 responden.

\section{HASIL PENELITIAN DAN PEMBAHASAN}

\section{Karakteristik Ekonomi Kreatif Subsektor Kuliner di Kota Pontianak.}

Kuliner tidak hanya soal cita rasa tetapi terdapat sisi kreatifitas yang dilakukan oleh pelaku dalam pengolahan dan penyajian serta ada sentuhan budaya setempat 
sehingga menghasilkan sajian yang indah dan memberikan nilai tambah yang pada akhirnya akan memajukan usaha kuliner serta memberikan kontribusi bagi perekonomian daerah. Kota Pontianak merupakan kawasan perkotaan dimana ruang lingkup ekonomi kreatif subsektor kuliner yang paling banyak ditemui di Kota Pontianak adalah warung makan, kedai makan dan kafe. Alasan yang dikemukakan para responden dalam menggeluti subsektor kuliner antara lain dikarenakan (1) keahlian dalam mengolah makanan/ minuman, (2) hobi, (3) prospek usaha bagus, (4) permintaan konsumen, dan (5) belum ada usaha sejenis di wilayah sekitar mereka berjualan.

Para pelaku ekonomi kreatif subsektor kuliner di Kota Pontianak memiliki karakteristik baik dari segi umur maupun pendidikan. Berdasarkan umur, bahwasanya puncak kreativitas dan inovasi manusia terjadi dalam waktu 10 tahun dari sekitar umur 32 tahun (Lin, 2002). Berarti kreativitas terjadi pada rentang umur 32-42 tahun. Fakta yang menarik ternyata usia para pelaku ekonomi kreatif subsektor kuliner di Kota Pontianak rata-rata berumur 40 tahun dan telah menggeluti usahanya kurang lebih lima tahun. Hal ini mengindikasikan pelaku subsektor kuliner pada usia ini mampu memaksimalkan potensi kreatifitas dan inovasi yang dimiliki. Pada rentang usia ini pula para pelaku dalam masa produktif dan mulai stabil dalam memutuskan kreatifitas dan inovasi usaha yang akan digunakan.

\section{Tabel 2. Jumlah Pelaku Ekonomi Kreatif Subsektor Kuliner Berdasarkan Pendidikan di Kota Pontianak}

\begin{tabular}{clcc}
\hline No & Tingkat Pendidikan & Jumlah & Persentase \\
\hline 1 & Tidak Sekolah & 5 & 1,74 \\
2 & SD & 35 & 12,20 \\
3 & SMP & 45 & 15,68 \\
4 & SMA/SMK & 147 & 51,22 \\
5 & D1 & 1 & 0,35 \\
6 & D3 & 9 & 3,14 \\
7 & S1 & 43 & 14,98 \\
8 & S2 & 2 & 0,69 \\
\hline \multicolumn{2}{r}{ TOTAL } \\
\hline
\end{tabular}

Karakteristik pelaku ekonomi kreatif subsektor kuliner berdasarkan pendidikan dapat dilihat pada tabel 2, dimana sebanyak 51,2\% dari total responden berpendidikan terakhir sekolah menengah atas. Hal ini mengindikasikan untuk menjadi pelaku subsektor kuliner tidak memerlukan syarat dari sisi pendidikan, sehingga semua orang dengan latar pendidikan apapun dapat berkecimpung di subsektor ini. Tetapi pendidikan tetap berperan dalam dalam membentuk kemampuan untuk menyerap teknologi modern dan untuk mengembangkan kapasitas sehingga meningkatkan pembangunan ekonomi wilayah tersebut (Todaro, M.P., \& Smith, 2006). Sesuai dengan teori human capital bahwasanya investasi dalam pekerjaan melalui pendidikan, pengalaman, keahlian dan pelatihan-pelatihan akan dihargai dalam lingkungan atau tempat kerja dan akan mendapatkan pekerjaan yang lebih baik (Hennekam \& Bennett, 2017). Oleh karenanya 
untuk bertahan ataupun unggul disubsektor ini para pelaku subsektor kuliner dapat meningkatkan keahliannya dengan belajar dan mencari pengalaman-pengalaman yang telah sukses dalam subsektor kuliner serta mengikuti pelatihan-pelatihan.

\section{Kreatifitas Ekonomi Kreatif Subsektor Kuliner di Kota Pontianak.}

Kreatifitas subsektor kuliner dilihat dari 5 sisi yakni melibatkan juru masak terlatih, menghasilkan menu baru secara rutin, mengandung makanan lokal, memberikan pengalaman kuliner bagi konsumen, dan telah menggunakan teknologi (Lazuardi \& Triady, 2015). Pada tabel 3 menggambarkan bahwasanya ekonomi kreatif subsektor kuliner di Kota Pontianak belum sepenuhnya memenuhi semua unsur kreatifitas dimana dari 5 sisi kreatifitas hanya sisi memberikan pengalaman kuliner bagi konsumen yang persentasenya diatas 50\% dan sisi melibatkan juru masak terlatih mendekati 50\%. Ketiga sisi lainnya menjadi catatan bagi kuliner di Kota Pontianak. Kemampuan untuk menumbuhkan kreatifitas dan meningkatkan inovasi bagi para pelaku ekonomi kreatif sangat diperlukan agar mampu tumbuh dan bersaing, serta mengubah orientasi tidak hanya keuntungan saja tetapi telah berorientasi pelanggan agar terbentuk kerja sama yang menguntungkan dalam jangka waktu yang panjang (Mulyana \& Sutapa, 2015). Upaya-upaya dalam menciptakan kreatifitas usaha dalam subsektor kuliner sangat penting dilakukan dikarenakan para pelaku ekonomi kreatif di subsektor ini menyadari bahwa usaha kuliner di Kota Pontianak berkembang pesat dan masih banyak peluang walaupun mulai banyak pesaing yang memiliki variasi dan rasa yang khas dalam setiap sajiannya.

Tabel 3. Kreatifitas Subsektor Kuliner di Kota Pontianak

\begin{tabular}{lrc}
\hline \multicolumn{1}{c}{ Kreatifitas Kuliner } & Ya & Tidak \\
\hline Melibatkan juru masak terlatih & $41,1 \%$ & $58,9 \%$ \\
$\begin{array}{l}\text { Menghasilkan menu baru } \\
\text { secara rutin }\end{array}$ & $8,4 \%$ & $91,6 \%$ \\
Mengandung makanan lokal & $14,3 \%$ & $85,7 \%$ \\
$\begin{array}{l}\text { Memberikan pengalaman } \\
\text { kuliner bagi konsumen }\end{array}$ & $51,2 \%$ & $48,8 \%$ \\
Telah menggunakan teknologi & $29,3 \%$ & $70,7 \%$ \\
\hline
\end{tabular}

Berdasarkan sampel sebanyak 287 ekonomi kreatif subsektor kuliner di Kota Pontianak, peneliti memilah kembali berdasarkan sisi kreatifitas sehingga menyimpulkan terdapat 10 usaha yang memiliki kreatifitas yang lebih dibandingkan dengan usaha yang lainnya. Hal ini dikarenakan ke-10 usaha tersebut menyediakan makanan tradisional dan minuman tradisional antara lain asam pedas, bubur pedas, cencalok, tempoyak, paceri nenas,sayur keladi, pisang goreng srikaya, mie tiaw, mi sagu, kue pancung, dan air lidah buaya. Sedangkan yang tidak menyediakan makanan khas Pontianak dikarenakan lingkungan sekitar pelanggan lebih banyak memilih menu yang praktis seperti ayam 
geprek, nasi goreng, mie tiaw serta harga yang terjangkau. Alasan pelaku subsektor kuliner tidak menyediakan makanan tradisional adalah biaya untuk produksi makanan tradisional cukup besar diabandingkan dengan menu yang praktis. Selanjutnya dari segi tempat ke-10 usaha tersebut memiliki tempat yang unik serta memberikan kesan yang nyaman untuk pembeli seperti menyediakan tempat makan di pinggir sungai dan menyediakan kapal pesiar untuk pelanggan bisa menikmat makanan yang disajikan sambil menelusuri serta menikmati keindahan sungai kapus secara lebih dekat, tempat bermain untuk anak-anak, ada tempat belajar serta perpustakaan mini yang disediakan untuk pembeli yang ingin makan sambil belajar ataupun mengerjakan tugas bersama teman-teman. Adapun pendapat dari beberapa pelanggan memilih tempat tersebut dikarenakan faktor kenyamanan dan cita rasa masakan yang enak.

\section{Structure-Conduct-Performance Ekonomi Kreatif Subsektor Kuliner di Kota Pontianak.}

Structure pada ekonomi kreatif subsektor kuliner di Kota Pontianak dapat dilihat dari sisi unit usahanya, dimana pada model bisnis subsektor kuliner terdiri dari tiga kategori yaitu independent, chain dan franchise (Lazuardi \& Triady, 2015). Berdasarkan data yang telah dikumpulkan, sebanyak 95,5\% model bisnis usaha kuliner di Kota Pontianak adalah independent. Model bisnis independent merupakan model bisnis yang dikelola secara mandiri dan dibuka pada satu daerah tertentu oleh pemilik usaha. Sisanya sebesar 2,1\% model bisnis chain dan 2,4\% model bisnis franchise. Model bisnis chain merupakan model bisnis yang dimiliki oleh pemilik usaha dengan mempunyai satu nama atau merek dan telah membuka cabang dibeberapa lokasi dengan standarisasi yang sama. Model bisnis franchise serupa dengan model bisnis chain, perbedaannya adalah pada model bisnis franchise pemilik setiap cabang bisa berbeda dikarenakan pemilik usaha menjual mereknya ke pihak lain. Beberapa pemilik usaha kuliner yang memiliki model bisnis independent sebenarnya dapat mengembangkan menjadi model bisnis chain agar penjualannya meningkat namun tidak dilakukan dengan alasan karena pengenaan pajak yang semakin tinggi, takut tidak berhasil, dan beberapa alasan lainnya yang menjadi permasalahan usaha mikro kecil menengah (UMKM) seperti modal.

Conduct pada ekonomi kreatif subsektor kuliner di Kota Pontianak dapat dilihat dari sisi penentuan harga dan pemasarannya. Penentuan harga yang dilakukan oleh pelaku ekonomi kreatif subsektor kuliner sebanyak 79,8\% (229 dari 287 responden) menyatakan menetapkan sendiri. Dari 229 responden 120 responden menetapkan harga sendiri setelah melihat informasi harga pesaing. Selanjutnya dalam memasarkan usahanya, para pelaku ekonomi kreatif menempuh berbagai cara untuk menarik pengunjung. Pada tabel 4 dapat dilihat bahwa kekuatan pemasaran mulut ke mulut tetaplah menjadi primadona dalam memasarkan usaha kuliner ini. Tetapi yang sangat disayangkan dengan era digital saat ini, hanya $12,9 \%$ yang memanfaatkan media sosial dalam pemasarannya. Padahal menurut data survei yang dilakukan oleh Asosiasi 
Penyelenggara Jaringan Internet Indonesia (APJII) mengungkap bahwa lebih dari setengah penduduk Indonesia kini telah terhubung ke internet. Survei yang dilakukan sepanjang 2016 itu menemukan bahwa 132,7 juta orang Indonesia telah terhubung ke internet. Adapun total penduduk Indonesia sendiri sebanyak 256,2 juta orang.

Tabel 4. Strategi pemasaran ekonomi kreatif subsektor kuliner di Kota Pontianak

\begin{tabular}{lll}
\multicolumn{1}{c}{$\begin{array}{c}\text { Cara Memasarkan } \\
\text { Produk }\end{array}$} & Ya & Tidak \\
\hline Mulut ke mulut & $87,1 \%$ & $12,9 \%$ \\
Pamflet & $49,1 \%$ & $50,9 \%$ \\
Media Sosial & $12,9 \%$ & $87,1 \%$ \\
Sponsor kegiatan & $6,6 \%$ & $93,4 \%$ \\
\hline
\end{tabular}

Performance pada ekonomi kreatif subsektor kuliner di Kota Pontianak dapat dilihat dari sisi omset yang dihasilkan setahunnya dan penyerapan tenaga kerja. Hasil survey mengenai omset perbulan dapat dilihat pada tabel 5. Tabel 5 menunjukkan bahwasanya subsektor kuliner mampu menghasilkan omset perbulan minimal Rp 400.000 dan bahkan mampu menghasilkan omset hingga lebih dari Rp 80.000.000 perbulan serta sebesar $62,4 \%$ pelaku subsektor kuliner di Kota Pontianak memiliki omset perbulan dibawah Rp 20.000.000. Berdasarkan potensi dari sisi omset usaha selanjutnya dapat menunjukkan skala usaha subsektor kuliner ini sesuai kriteria yang dijelaskan dalam Undang-Undang Republik Indonesia No.20 Tahun 2008 Tentang Usaha Mikro, Kecil, dan Menengah (Menteri Hukum dan HAM RI, 2008) sehingga dapat disimpulkan skala usaha subsektor kuliner di Kota Pontianak sebagian besar masih tergolong kriteria usaha mikro.

Tabel 5. Omset Ekonomi Kreatif Subsektor Kuliner di Kota Pontianak

\begin{tabular}{clc}
\hline No & Total Omset Perbulan & Jumlah Sampel \\
\hline 1 & $<\operatorname{Rp~20.000.000~}$ & 179 \\
2 & Rp 20.000.000-Rp 40.000.000 & 73 \\
3 & Rp 40.000.000-Rp 60.000.000 & 17 \\
4 & Rp 60.000.000-Rp 80.000.000 & 12 \\
5 & $>\operatorname{Rp~80.000.000~}$ & 6 \\
& & 287 \\
\hline
\end{tabular}

Meningkatnya omset subsektor kuliner akan berdampak pada penyerapan tenaga kerja, 88,2\% subsektor kuliner di Kota Pontianak telah memiliki tenaga kerja 1-4 orang dan 11,8\% memiliki tenaga kerja sebanyak 5-19 orang. Berdasarkan kuantitas tenaga kerja, Badan Pusat Statistik Indonesia mengkategorikan skala usaha mikro dengan tenaga kerja 1-4 orang, usaha kecil memiliki jumlah tenaga kerja 5-19 orang, dan usaha menengah memiliki tenaga kerja 20-99 orang. Oleh karenanya berdasarkan kategori BPS 
dapat disimpulkan sebagian besar subsektor kuliner di Kota Pontianak ini masih tergolong usaha mikro.

\section{SIMPULAN}

Ruang lingkup ekonomi kreatif subsektor kuliner yang paling banyak ditemui di Kota Pontianak adalah warung makan, kedai makan dan kafe. Karakteristik pelaku ekonomi kreatif subsektor kuliner di Kota Pontianak rata-rata berumur 40 tahun, sebagian besar berpendidikan SMA dan telah menggeluti usahanya kurang lebih lima tahun. Ekonomi kreatif subsektor kuliner di Kota Pontianak belum sepenuhnya memenuhi semua unsur kreatifitas dimana dari 5 sisi kreatifitas hanya sisi memberikan pengalaman kuliner bagi konsumen yang persentasenya diatas 50\%. Berdasarkan pendekatan SCP, Structure pada ekonomi kreatif subsektor kuliner di Kota Pontianak dapat dilihat dari sisi unit usahanya masih bersifat independent. Conduct pada subsektor ini dilihat dari sisi penentuan harga yang sebagian besar menetapkan harga sendiri tanpa melihat informasi harga pesaing dan pemasarannya masih menggunakan cara memasarkan mulut ke mulut. Performance pada subsektor ini dilihat dari sisi omset yang sebagian besar masih berskala mikro.

Ekonomi kreatif subsektor kuliner di Kota Pontianak memiliki potensi untuk dikembangkan sehingga dapat memberikan kontribusi bagi perekonomian daerah. Hal ini dikarenakan: (1) Kota Pontianak yang tergolong kawasan perkotaan dan sebagai ibukota Propinsi Kalimantan Barat memiliki daya tarik wisata kuliner khususnya bagi penduduk Kalimantan Barat, (2) Masih banyak kuliner lokal yang dapat dikreasikan dan dibuat dengan sentuhan tradisional maupun modern untuk disajikan, (3) Mudahnya menjadi pelaku usaha di subsektor kuliner dimana tidak ada syarat usia dan latar belakang pendidikan dikarenakan keberhasilan subsektor kuliner ini lebih ditentukan oleh kreatifitas rasa dan penyajian. Selanjutnya kreatifitas subsektor kuliner di Kota Pontianak sudah selayaknya semakin kreatif dengan memenuhi kategori kreatifitas dalam subsektor ini yaitu melibatkan juru masak terlatih, menyediakan menu baru khususnya berbahan dasar khas daerah yang selanjutnya dapat diolah sehingga menciptakan cita rasa baru, memanfaatkan akses media sosial yang saat ini mudah dijangkau dan digunakan untuk memasarkan usahanya serta memberikan pengalaman kuliner bagi para konsumennya.

\section{UCAPAN TERIMA KASIH}

Terimakasih kepada DRPM Kemenristekdikti yang telah memberikan hibah Penelitian Dosen Pemula Tahun 2017. 


\section{DAFTAR PUSTAKA}

Arsyad, L., \& Kusuma, S. E. (2014). Ekonomika Industri Pendekatan Struktur, Perilaku dan Kinerja. Yogyakarta: UPP STIM YKPN.

Bakhshi, H., MacVittie, E., \& Simmie, J. (2008). Creating innovation. Do the creative industries support innovation in the wider economy? National Endowment for Science, Technology and the Arts (NESTA). https://doi.org/10.1108/EUM0000000006035

Carr, J. (2009). Creative Industries, Creative Workers and the Creative Economy: a Review of Selected Recent Literature. Scottish Government Social Research.

Departemen Perdagangan RI. (2009). Studi Industri Kreatif Indonesia. Jakarta.

Fleming, R. C. (2009). Creative Economic Development, Sustainability, and Exclusion in Rural Areas. Geographical Review, 99(1), 61-80. https://doi.org/10.1111/j.19310846.2009.tb00418.x

Hennekam, S., \& Bennett, D. (2017). Creative industries work across multiple contexts: common themes and challenges. Personnel Review, 46(1), 68-85. https://doi.org/10.1108/PR-08-2015-0220

Higgs, P., \& Cunningham, S. (2008). Creative Industries Mapping: Where have we come from and where are we going? Creative Industries Journal, 1(1), 7-30. https://doi.org/10.1386/cij.1.1.7_1

Kementerian Pariwisata dan Ekonomi Kreatif RI. (2014). Kekuatan Baru Indonesia Мепији 2025. Jakarta.

Khavidhurrohmaningrum. (2013). Strategi dan Perilaku Industri Pengolahan di Kota Semarang Tahun 2007-2011. Economics Development Analysis Journal, 1(2), 220 233.

Kimatu, J. N. (2016). Evolution of strategic interactions from the triple to quad helix innovation models for sustainable development in the era of globalization. Journal of Innovation and Entrepreneurship, 5(1), 16. https://doi.org/10.1186/s13731-0160044-x

Lazuardi, M., \& Triady, M. S. (2015). Ekonomi Kreatif: Rencana Pengembangan Kuliner Nasional. PT. Republik Solusi.

Lin, S. Optimum Strategies for Creativity and Longevity (2002). Retrieved from http://xa.yimg.com/kq/groups/22416650/836839594/name/RetirementAgevsLifeSp an1121.pdf

Mahesa, B. (2010). Analisis Struktur, Perilaku dan Kinerja Industri Minuman di Indonesia Periode 2006 - 2009. Media Ekonomi, 18(3), 1-18.

Menteri Hukum dan HAM RI. UU No.20 Tahun 2008 Tentang Usaha Mikro, Kecil, dan Menengah, Pub. L. No. 93 (2008). Indonesia: Sekretariat Negara RI.

Menteri Pariwisata RI. (2016, April 2). Kuliner Memiliki Peran Strategis Memperkuat Identitas Bangsa. Republika. Retrieved from http://www.republika.co.id/berita/gaya-hidup/kuliner/16/04/02/o4zjgy359-kulinermemiliki-peran-strategis-memperkuat-identitas-bangsa 
Miles, I., \& Green, L. (2008). Hidden innovation in the creative industries. National Endowment for Science, Technology and the Arts (NESTA). London. https://doi.org/10.5172/impp.11.2.148

Moelyono, M. (2010). Menggerakkan Ekonomi Kreatif Antara Tuntutan dan Kebutuhan. Rajawali Pers.

Mulyana, \& Sutapa. (2015). Peran Quadruple Helix dalam Meningkatkan Kreativitas dan Kapabilitas Inovasi (Studi Pada Industri Kreatif Sektor Fashion). In 2nd Conference in Business, Accounting, and Management (pp. 222-232).

Suryana. (2013). Ekonomi Kreatif, Ekonomi Baru: Mengubah Ide dan Menciptakan Peluang. Jakarta: Salemba Empat.

Todaro, M.P., \& Smith, S. . (2006). Pembangunan Ekonomi (Kesembilan). Jakarta: Erlangga.

Triwibowo, H. S. (2016, Desember). Kota Pontianak Miliki 17 Ribu Pelaku Usaha. Tribun Pontianak. Retrieved from http://pontianak.tribunnews.com/2016/12/03/kota-pontianak-miliki-17-ribu-pelakuusaha 